\title{
Infarto pulmonar cavitado
}

\section{Cavitated pulmonary infarction}

\author{
Jorge Alberto Carrillo, Paula Andrea Rodríguez, \\ Marta Paola González, Juan Mauricio Pardo • \\ BOGotÁ, D.C. (COLOMBIA)
}

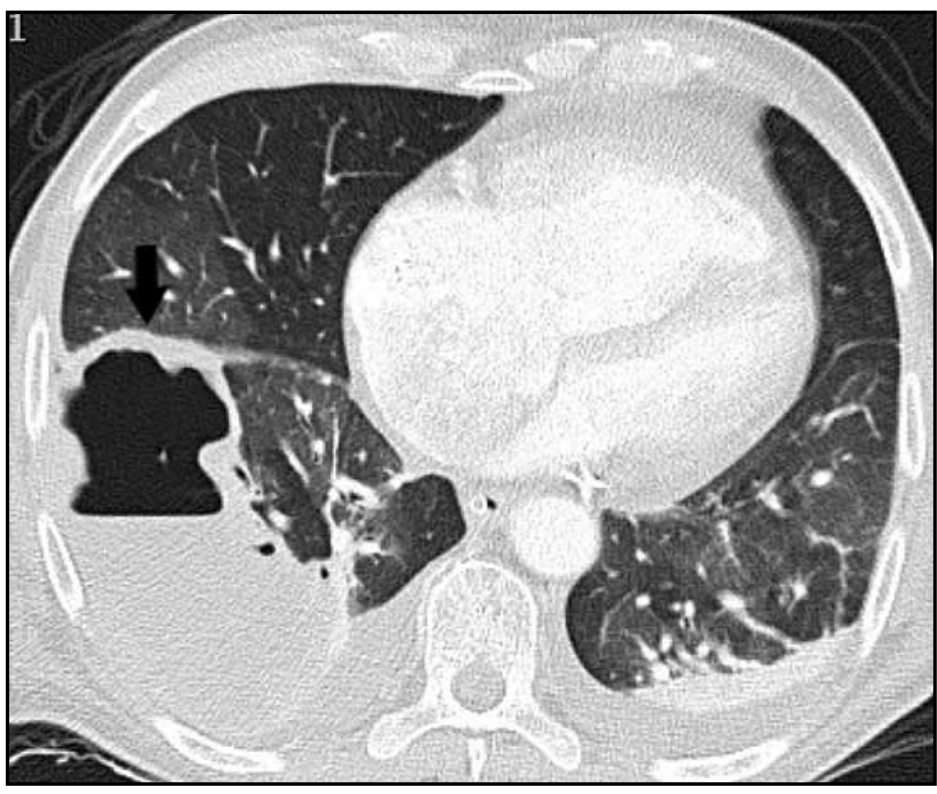

Figura 1. TC tórax contrastada.

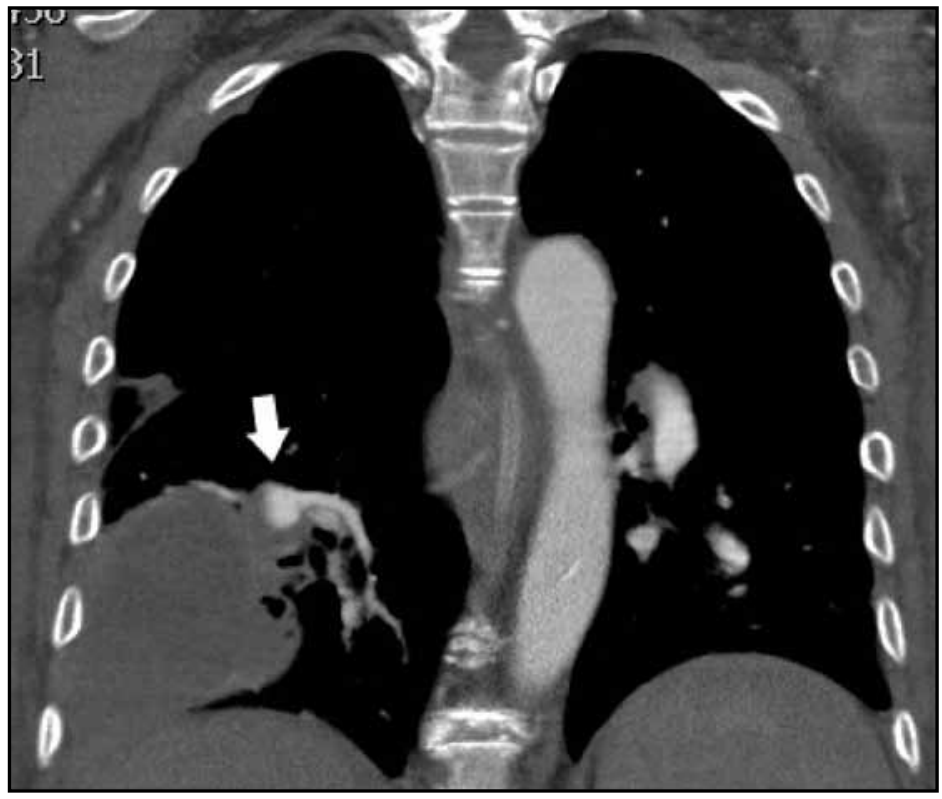

Figura 2. TC tórax contrastada. Oclusión arteria interlobar.
Paciente de 48 años con cuadro de un mes de dolor torácico, tos con expectoración purulenta y fiebre. Remitido para manejo con diagnóstico de absceso pulmonar.

La TC de tórax contrastada demostró masa pulmonar cavitada (Figura 1) y oclusión de la arteria interlobar derecha (Figura 2), que confirmó el diagnóstico de infarto pulmonar.

Se define masa pulmonar como una opacidad parenquimatosa con diámetro mayor de $3 \mathrm{~cm}$, independiente de las características de sus contornos, bordes y densidad. El término de cavitación se refiere a la presencia de áreas de menor densidad (líquido-aire) dentro de un nódulo, una masa o consolidación del parénquima pulmonar.

El diagnóstico diferencial de masa pulmonar cavitada es amplio e incluye entidades congénitas (secuestro pulmonar, quiste broncogénico), infecciosas (absceso pulmonar bacteriano, actinomicosis, tuberculosis, aspergilosis, mucormicosis), neoplásicas (carcinoma broncogénico, metástasis, linfoma), vasculares (infarto pulmonar), inmunológicas (poliangeítis con granulomatosis, granulomatosis eosinofílica con poliangeítis) y misceláneas (amiloidosis).

\section{Referencias}

1. Rajagopala S, Devaraj U,D'Souza G. Infected Cavitating Pulmonary Infarction. Resp Care 2011; 56: 707-709

2. Bray T, Mortensen K, Gopalan D. Multimodality Imaging of Pulmonary Infarction. Eur J Radiol 2014.
Dr. Jorge Alberto Carrillo: Especialista en Radiología Méderi, Profesor Universidad del Rosario; Srtas. Paula Andrea Rodríguez Ordóñez y Marta Paola González Alba: Estudiantes Universidad del Rosario; Dr. Juan Mauricio Pardo Oviedo: Especialista en Medicina Interna, Medicina Crítica e Intensiva y en Fisiología de la Ciencia. Jefe de Educación Médica Méderi, Profesor Principal Universidad del Rosario. Bogotá, D.C. (Colombia). Correspondencia: Dr. Juan Mauricio Pardo Oviedo. Bogotá, D.C. (Colombia).

E-mail: juan.pardo@urosario.edu.co

Recibido: 11/XI/2014 Aceptado: 29/V/2015 